\title{
Recurrent Extensive Stage Lung Small Cell
} Carcinoma

National Cancer Institute

\section{Source}

National Cancer Institute. Recurrent Extensive Stage Lung Small Cell Carcinoma. NCI

Thesaurus. Code C141077.

Extensive stage small cell lung carcinoma that has reemerged after a period of remission. 